\title{
Prediction of Tele-Tsunami from Canary Island on the West African Coastal Region
}

\author{
Eze, C. L. \\ Institute of Geosciences and Space Technology, Rivers State University of Science and Technology, Port Harcourt, Nigeria
}

\begin{abstract}
Many tsunamis are known to have been triggered by landslides. Landslides can happen almost any place where the ground surface slopes and some of the largest landslides on Earth have been found to occur underwater. A primary hazard of submarine landslides, is landslide-generated tsunami waves. Submarine faulting moves the seafloor vertically while offshore slumping of sediments displaces large mass of water in the form of tsunami. Tsunamis from strong earthquakes can travel across the Atlantic Ocean basin. The threat of mega tsunami generation from the postulated massive slope failure of the CumbreViejastrato volcano on La Palma and the far field effects in the Atlantic coast of West Africa have been assessed. CumbreVieja's western flank appears to be relatively unstable and this flank could undergo a large-scale, gravitational collapse which could occur suddenly with little or no precursory deformation. The whole side of CumbraVieja volcano collapsing into the ocean would produce a large tsunami. The possible impact of such an event on the coast of West Africa is here examined. It has been shown that after 6 hours the tsunami will hit the east coast of South America. This point will most likely act as a new source of waves according to Hughen's principle. This wave travelling eastward oppos ite the original wave will lead to a wave superimposition and constructive interference at some point. The estimated travel time for the waves to reach West Africa coastal region is about 12 hours. The ultimate damage that will be done by such a tsunami does not depend only on the wave strength and run-up but also on the high Tsunami Avoidable Susceptibility Index (TASI) of the region.
\end{abstract}

Keywords: Volcanic Island, Canary Island, CumbraVieja volcano, Tele-tsunami, West African coast

\section{Introduction}

Many tsunamis are known to have been triggered by landslide. Landslides can happen almost any place where there is a sloping surface including the sea. The largest landslides have been reported to occur underwater (Kowalik, 2012). Seismic events are known to trigger these landslides. Other underwater landslides are however, located on seismically quiet continental passive margins, such as the east and west edges of the Atlantic Ocean, and on the flanks of oceanic island volcanoes such as Hawaii, the Canaries and Azores (Ward and Day, 2001).A primary hazard of submarine landslides is landslide-generated tsunami waves. Submarine faulting moves the seafloor vertically while offshore slumping of sediments displaces large mass of water in the form of tsunami (Kowalik, 2012). The tsunami can travel across the Atlantic Ocean basin as tele-tsunami and cause damage at the coastal regions.

Tele-tsunamis are tsunamis felt in an area far away from the source. It is technically defined as a tsunami originating at a distance of more than one wave length from the point of observation. The 2004 Indonesian tsunami travelled across the Indian Ocean to east Africa. There is paucity of reports of strong tsunamis at significant distances from the past centres of strong earthquakes in the Atlantic Ocean or the Caribbean. In spite of this paucity of records risk estimation still needs to be carried out to at least assuage the fears of the people potentially at risk. The populace and facilities considered as being potentially at risk are the ones within $15 \mathrm{~m}$ elevation above sea level.

\section{Tsunami from Volcanic Islands}

The history as well as the potentials of tsunamis in the Atlantic from the Azores has been studied by many workers (Udiaset al., 1976; Moreira, 1985; Moreira, 1988). The historic tsunami of 1757 is the most important tsunami recorded in the Azores region. This tsunami was reported to have struck Graciosa, St. Jorge islands, Pico and Terceira (Moreira, 1988). The heights of tsunami waves from distant sources such as those generated by the 1755 Lisbon earthquake have been estimated with numerical models (Mader, 2001). Other recorded tsunamis in the region include the small tsunami set off by the earthquake of August 31, 1926, a small tsunami of 1939 and relatively recently in 1980, an earthquake in Azores set off another tsunami recorded by seismic stations in Azores (Udiaset al., 1976; Moreira 1985; Moreira, 1988). The fracture zone extending from the Azores towards the Strait of Gibraltar is the boundary between the Eurasian and African tectonic plates. Seismotectonic studies show the prolongation of the Azores-Gibraltar fault through the North of Africa up to Sicily (Campos, 1991).Doxsee, (1948) noted that a "sea wave" (presumably a tsunami) was reported at the Azores from the 1929 Grand Banks earthquake off Newfoundland.

Minster and Jordan (1978) and Buforn et al., (1988) independently carried out analysis of the earthquake focal mechanisms in this zone and showed that the relative motion between the two plates changes from right lateral strike slip with an extensional component at the western end, to pure strike slip in the central area and thrusting with a compressive component in the NW direction at the eastern end.

Many workers have reported the lateral collapse of volcanic mountains from various locations. According to Smith and Shepherd, (1993) about 5\% of all tsunamis are estimated to have been caused by volcanic activities and at least one fifth of these result from volcanically induced landslides. Moore, (1964) identified the remains of lateral collapses off the flanks of Hawaii. Since then, many more have been recognized adjacent to island volcanoes in nearly every ocean. These are very large landslides attaining volumes of 


\section{International Journal of Science and Research (IJSR) \\ ISSN (Online): 2319-7064 \\ Index Copernicus Value (2013): 6.14 | Impact Factor (2015): 6.391}

several thousand cubic kilometers and lengths of more than $200 \mathrm{~km}$.

(Moore et al., 1994).

Keating and McGuire (2000) listed some historic examples of tsunamis induced by flank collapse of volcanic mountain. In 1792, a small subaerial landslide at Mt. Unzen volcano in Japan generated destructive waves when in the Ariake Bay. Submarine landslides generated by lateral collapse of the Krakatou volcano produced tsunami waves as much as $40 \mathrm{~m}$ high. Tanioka, (1999) opined that it seems likely the earthquake near Aitape triggered a submarine landslide on the steep island slope and that the landslide created the Great Kuril Tsunami of 1994.

In the Flores island tsunami in 1992 there exist clear pictures of evidence of landslide trace and this landslide affected the tsunami characteristics locally (Imamura et al., 1993). In 1977 several large scale landslide traces were found near the Sanriku coast in Japan (Honzaet al., 1978). It was discovered that one of these landslides would have a potential to generate a large tsunami.

\section{Tele-tsunami from the Canary Island}

The threat of mega tsunami generation from the postulated massive slope failure of the Cumbre Vieja volcano on La Palma and the far field effects in the Eastern Atlantic from such an unlikely but possible event, have been assessed (Pararas-Carayannis, 2002). Mader, (2001) modeled the tsunami expected from a lateral collapse of the Cumbre Vieja Volcano on La Palma in the Canary Islands. The resultant wave height from the model on African coasts was about $10 \mathrm{~m}$. Ward and Day, (2001) carried out a simulation of the collapse of St. Helen Mountain, La Palma and reported that the collapse could send as much as 500 cubic kilometers of rock in the form of a debris avalanche into the Atlantic Ocean, triggering a tsunami. Gisler et al., (2006) reported the findings of two-dimensional and threedimensional simulations of a hypothetical tsunami resulting from the lateral flank collapse of the Cumbre Vieja volcano on the island of La Palma in the Canary Islands and came to the same conclusions as Ward and Day.

The Canary Islands are formed by what is believed to be the remaining cones of long-extinct volcanoes now existing as an archipelago situated off the coast of northwest Africa.

There are seven large islands and numerous smaller islands that collectively make up the Canary Islands (Carracedo, 1994) (Figure 1). Tenerife is the largest island within the archipelago. The Teide volcano, located on the island of Tenerife, has a summit of $3,718 \mathrm{~m}$ making it the highest point within the Canary and also the highest point above sea level in the islands of the Atlantic. The lowest point of the Canary Islands is the Atlantic Ocean. The Teide remains active, although its last eruption occurred in 1909 (Banda et al., 1981).

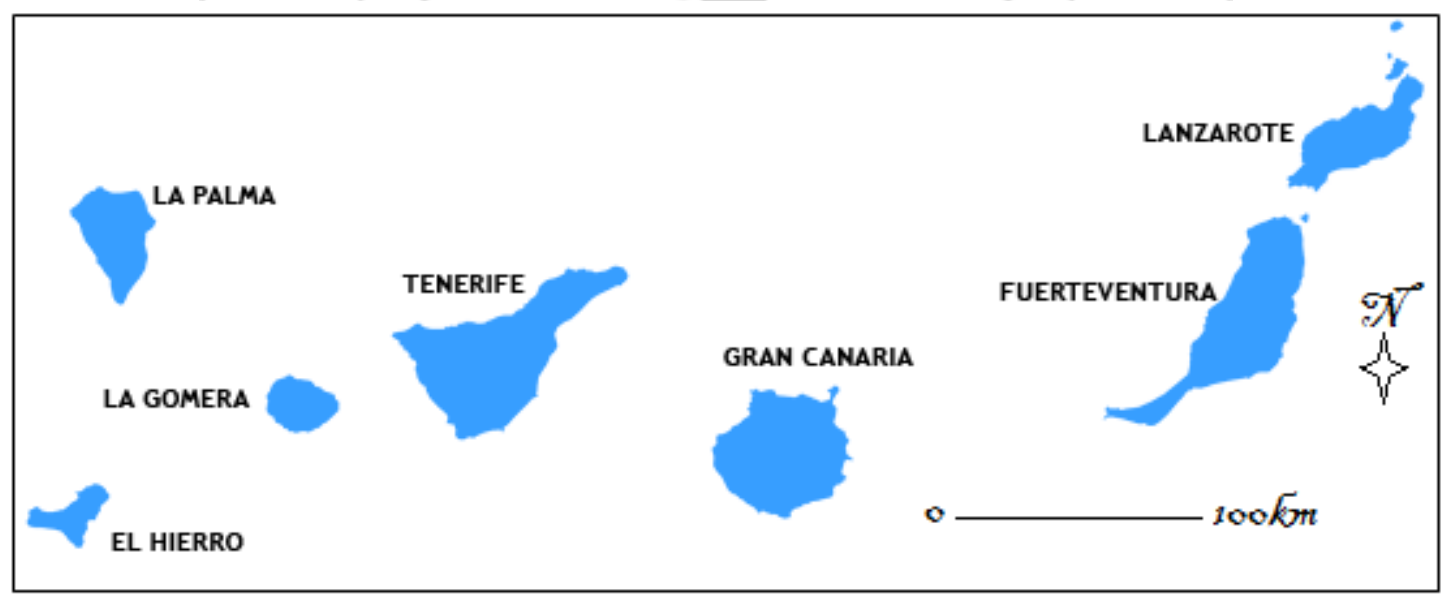

Figure 1: CanaryIsland

Cumbre Vieja is an active volcanic ridge which trends in an approximate north-south direction and covers the southern third of the island. It is currently the most volcanically active of the Canary Isles.

Tsunami list among the many hazards associated with lateral collapses of volcanoes (Ward and Day, 2001) and the Atlantic Ocean is replete with volcanic islands. Day et al., (1999a, 1999b) reported that at least two of these volcanoes show signs of incipient instability. Cumbre Vieja's western flank appears to be relatively unstable andthis flank could undergo a large-scale, gravitational collapse which could occur suddenly with little or no precursory deformation. The whole side of Cumbra Vieja volcano collapsing into the ocean would produce a large tsunami (Pararas-Carayannis, 2002). The possible impact of such an event on the coast of West Africa is here examined.

Landslide duration $T_{C}$, and mean slide velocity $\bar{V}$ are important factors affecting the magnitude of the resultant tsunami. The duration of the landslide causing the tsunami depends on the length $L_{C}$, of the slide from the block toe to the slide toe and the initial slope angle $\phi$ (Figure 2). 


\section{International Journal of Science and Research (IJSR) \\ ISSN (Online): 2319-7064}

Index Copernicus Value (2013): 6.14 | Impact Factor (2015): 6.391

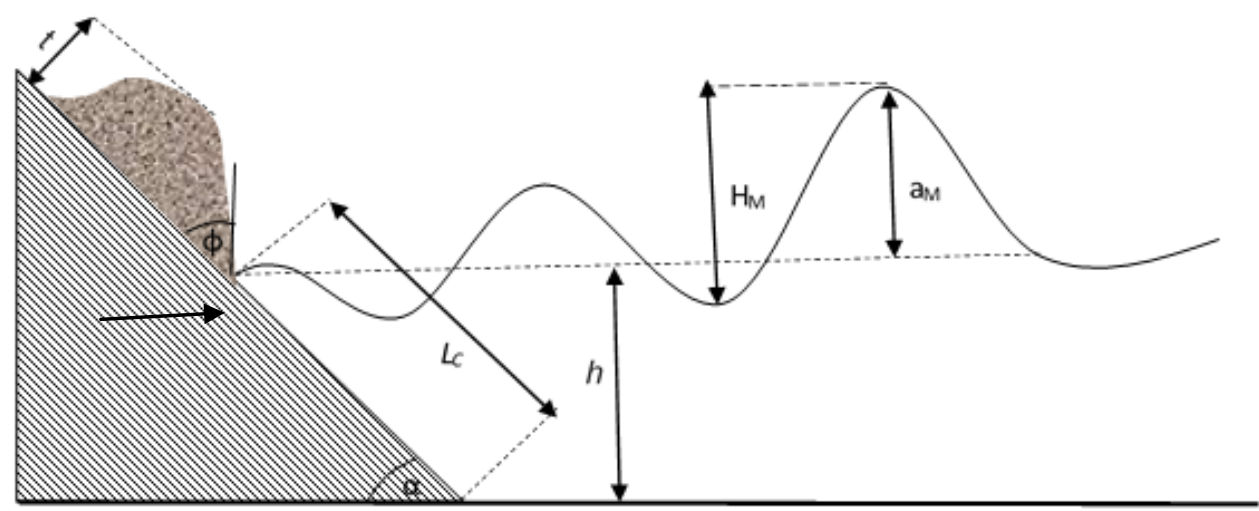

Figure 2: Landslide-Generated Tsunami

$$
T_{c}=\sqrt{8 L_{c} / g \sin \phi}
$$

The mean slide velocity is given by

$$
\bar{V}=\sqrt{\frac{g L_{C} \sin \phi}{8}}
$$

$$
g=\text { acceleration due to gravity }\left(9.8 \mathrm{~ms}^{-2}\right)
$$

The maximum wave height $\mathrm{H}_{\mathrm{M}}$ and consequently the maximum wave amplitude $a_{M}$ will be attained as the wave travel from the open sea to the coast due to shoaling effect. In a constant depth basin the wave will suffer geometric spreading and the wave height $H$ as a function of distance from source is given as:

$$
H=H_{O} \frac{R_{O}}{R}
$$

$R_{O}$ is the initial source radius, $\mathrm{R}$ is the distance the wave has traveled from the source, and $\mathrm{H}_{\mathrm{o}}$ is the initial height of the source.

Shallow water tsunami propagation model in the spherical coordinates has been used to simulating propagation of tsunamis from the Canaries islands over long distances. The directivity of the wave energy is quite important. Most of the energy propagates perpendicular to the fault orientation (Ward, 1980). Offshore, the waves may be strongly reflected and refracted by submarine structures like sea-mounts which acts as secondary sources. Waves eventually reaching the West African coast may in this case be originating from the structure and not from the earthquake epicenter. Heinrich et al., (1994) demonstrated that at one hour and a half after the origin time, waves from Azores reflected by the Moroccan coasts reached the south Portuguese and Spanish coasts. In similar manner the coast of countries in Central and South America have the possibility of reflecting the waves from Canary volcanic Islands to West African coast.The tsunami that may result from the landslide caused by the flank collapse of Cumbre Vieja can be described by the basic linear shallow water wave equation.

$$
\begin{array}{r}
\frac{\delta U}{\delta \mathrm{t}}+\mathrm{gH} \frac{\delta \eta}{\delta \mathrm{x}}=0 \\
\frac{\delta \mathrm{V}}{\delta \mathrm{t}}+\mathrm{gH} \frac{\delta \eta}{\delta \mathrm{y}}=0
\end{array}
$$

$$
\frac{\delta \eta}{\delta \mathrm{t}}+\left(\frac{\delta \mathrm{U}}{\delta \mathrm{x}}+\frac{\delta \mathrm{V}}{\delta \mathrm{y}}\right)=0
$$

Where:

$\mathrm{H}=$ Water depth

$\eta=$ The vertical displacement of the water surface above the equipotential surface

$\mathrm{t}=$ Elapse time

$\mathrm{U}$ and $\mathrm{V}=$ The horizontal and vertical components of the water surface

$\mathrm{x}$ and $\mathrm{y}=$ The spatial coordinates of the wave

$\mathrm{g}=$ The gravity acceleration

Shallow water approximation is valid if the water depth is much less than the wavelength $(\lambda)$. In this case, $\mathrm{H}<<\lambda$, $\mathrm{kH}<<1$ and $\tanh (\mathrm{kH})=\mathrm{kH}$ and nonlinear effects can be neglected.

Annunziato (2007) showed that after 6 hours the tsunami generated by the collapse of Cumbre Vieja's western flank will hit the east coast of South America (Figure 3). This point will most likely act as a new source of waves according to Hughen's principle. This reflected wave travelling eastward opposite the original wave will lead to a wave super imposition and interference which at some point will be constructive.

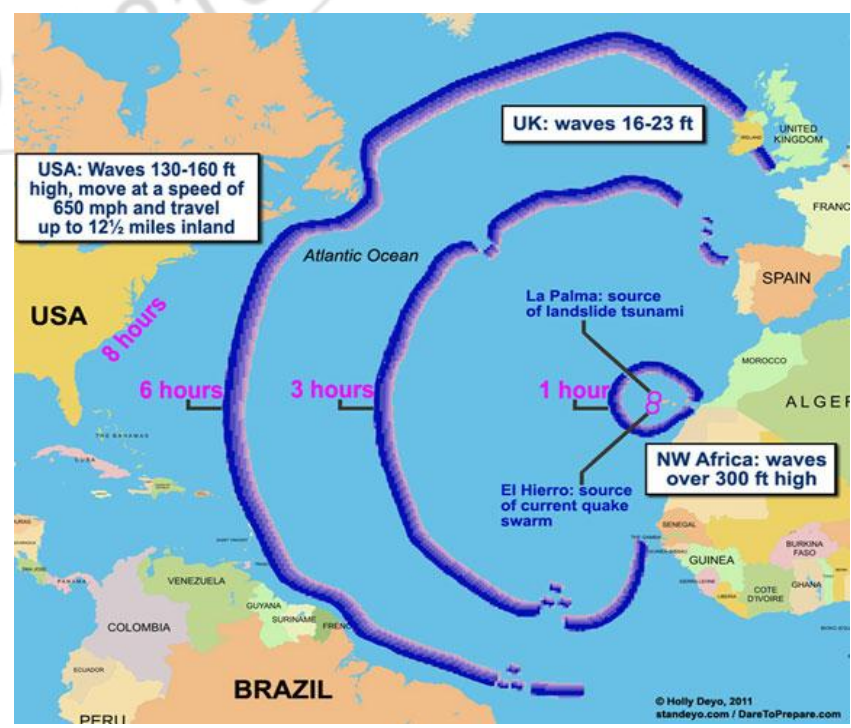

Figure 3: Travel time image calculated for the Canary Island case (After Annunziato, 2007) 


\section{International Journal of Science and Research (IJSR) \\ ISSN (Online): 2319-7064}

Index Copernicus Value (2013): 6.14 | Impact Factor (2015): 6.391

The wave will further be amplified by shoaling at the coast according to the shoaling coefficient $K_{s}$. The final wave height at the shoreline $H_{s}$ will be a product of the deep water wave height $H_{o}$ and the shoaling coefficient.

$$
H_{s}=H_{o} K_{s}
$$

The assumption is made that there exists no loss or gain of energy from the system.

This final wave arriving the coast of West Africa will have the potential of causing significant damage in the region. The damage will be particularly significant because of the high Tsunami Avoidable Susceptibility Index (TASI) associated with the West African coast.

\section{Conclusions}

The CanaryIsland provides a potential source of tsunami in the Atlantic Ocean. There is a possibility of the tsunami striking the South American coast and reflecting back to the West African coast. In the event of this happening, West African coastal region may be significantly impacted particularly because of the high tsunami avoidable susceptibility index of the region.

\section{References}

[1] Annunziato, A. (2007). The tsunami assessment modelling system By the joint research centre, Science of Tsunami Hazards, 26(2): 70-92

[2] Banda, E., Dafiobeitia, J.J., Surifiach, E. and Ansorge, J. (1981). Features of crustal structure under the Canary Islands. Earth Planet. Science Letter, 55:11-24.

[3] Buforn E., Udias, A and Colombas M. A.(1988). Seismicity, source mechanisms and tectonics of the Azores-Gilbraltar plate boundary. Tectonophysics, 152: 89-118.

[4] Campos, M. L. (1991). Tsunami Hazard on the Spanish Coasts. Science of Tsunami Hazards, 9(1): 8390

[5] Carracedo, J. C. (1994). The Canary Islands: an example of structural control on the growth of large oceanic-island volcanoes. Journal of Volcanology and Geothermal Research, 60: 225-241000

[6] Day, S.J., Carracedo, J.C., Guillou, H. and Gravestock, P. (1999a). Recent structural evolution of the Cumbre Vieja volcano, La Palma, CanaryIslands. Journal of Volcanology and Geothermal Research, 94: 135-167.

[7] Day, S.J., Heleno S.I.N., and Fonseca J.F.B.D.(1999b). A pastgiant lateral collapse and present day flank instability of Fogo, CapeVerde Islands. Journal of Volcanology and Geothermal Research,94:191-218.

[8] Doxsee, W.W. (1948). The Grand Banks Earthquake of November 18, 1929.Publicationsof the Dominion Observatory, Canada Department of Mines and Technical Surveys, Ottawa, Ontario, 7 (7): 323-335.

[9] Gisler, G., Weaver, R. and Gittings, M. L. (2006).Sage Calculations of the Tsunami Threat from La Palma. Journal of Tsunami Hazards, 24(4): 288-301
[10] Heinrich, P. H., Baptista, M. A and Miranda, P. (1994). Numerical Simulation of the 1969 Tsunami along the Portuguese coasts. Preliminary results. Science of Tsunami Hazards, 12(1): 3-24

[11] Honza, E., Tamaki, K., and Murakami, F. (1978). Geological map of the Japan and Kurile Trenches and adjacent areas: Marine geological map series 11: Tokyo (Geological Survey of Japan).

[12] Imamura, F., Shuto, N., Ide, S., Yoshida, Y., and Abe, Ka., 1993, Estimate of the tsunami source of the 1992 Nicaraguan earthquake from tsunami data.Geophysical Research Letter, 20: 1515-1518.

[13] Keating, B.H. and W.J. McGuire, (2000). Island edifice failures and associatedtsunami hazards. Pure and Applied Geophysics. 157:899-955.

[14] Kowalik, Z. (2012). Introduction to Numerical Modeling of Tsunami Waves. Institute of Marine Science University of Alaska, Fairbanks: 196pp

[15] Mader C. L. (2001). Modeling the La Palma Landslide Tsunami. Science of Tsunami Hazards, 19: 150-170.

[16] Minster J. B, and Jordan, T. H, (1978). Present day plate motions. Journal of Geophysical Research, 83:5331-5354.

[17] Moore, J.G.(1964). Giant submarine landslides on the Hawaiian ridge. U.S. Geological Survey Professional Paper 501-D, 95-98.

[18] Moore, J.G., Normark, W.R. and Holcomb, R.T., (1994). Giant Hawaiian Landslides. Annual Reviews ofEarth and Planetary Science, 22: 119-144.

[19] Moreira, V. S. (1985). Seismotectonics of Portugal and its adjacent area in the Atlantic.Tectonophysics, 117: 85-96.

[20] Moreira, V. S. (1988). Historical and Recent Tsunamis in the European Area. Science of Tsunami Hazards, 6(1): 37-42.

[21] Pararas-Carayannis, G. (2002). Near and Far-Field Effects of Tsunamis Generated by the Paroxysmal Eruptions, Explosions, Caldera Collapses and Slope Failures of the Krakatau Volcano in Indonesia, on August 26-27, 1883.Journal of Tsunami Hazards, 21(4): 191-221

[22] Smith, M. S. and Shepherd, J. B., (1993). Preliminary investigations of the tsunami hazard of Kick 'em Jenny submarine volcano. Natural Hazards 7(3): 257-278.

[23] Tanioka, Y. (1999): Analysis of the far-field tsunamis generated by the 1998 Papua New Guinea earthquake. Geophysical Research Letters, 26:3393-3396

[24] Udias, A.; Lopez Arroyo, A.; Mezciia, J. (1976) Seismotectonics of the Azores-Aiboran region. Tectonophysics, 31: 259-289.

[25] Ward S. N., (1980). Relationships of tsunami generation and an earthquake source. Journal of Physics of the Earth, 28: 441-474.

[26] Ward, S. N. and Day, S. (2001). Cumbre Vieja Volcano - potential collapse and tsunami at La Palma, Canary Islands.Geophysical Research Letters 28: 397-400 